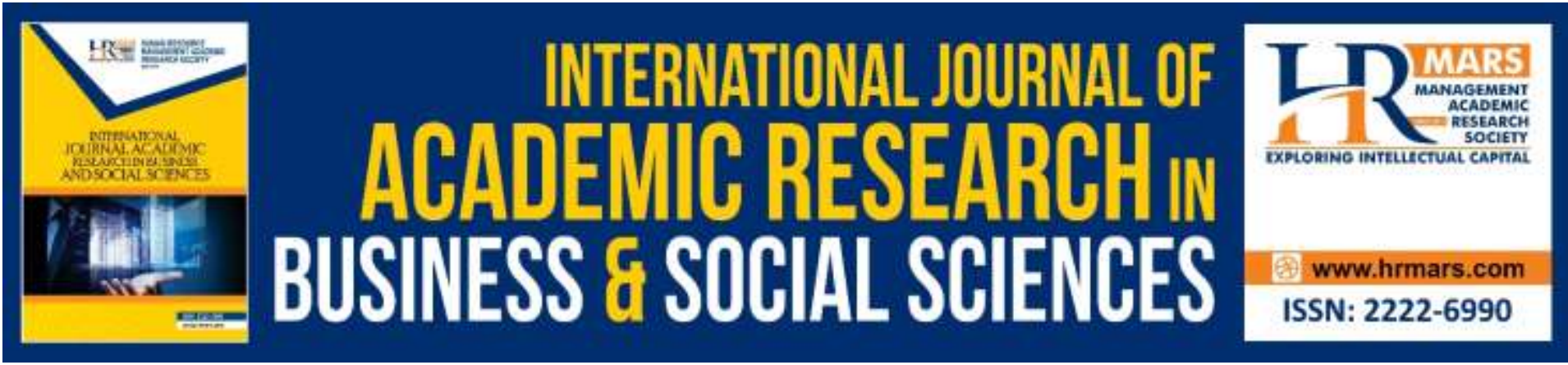

\title{
Impact of "Think-Pair-Share" and "Wait-Time" on Teaching and Learning Undergraduates: An Action Research
}

Ani Munirah Mohamad, Eshaby Mustafa, Nur Aili Hanim Hanafiah, Nurhazlina Mohd Ariffin, Ain Husna Mohd Arshad

To Link this Article: http://dx.doi.org/10.6007/IJARBSS/v9-i7/6184

DOI: 10.6007/IJARBSS/v9-i7/6184

Received: 22 May 2019, Revised: 19 June 2019, Accepted: 29 June 2019

Published Online: 25 July 2019

In-Text Citation: (Mohamad, Mustafa, Hanafiah, Ariffin, \& Arshad, 2019)

To Cite this Article: Mohamad, A. M., Mustafa, E., Hanafiah, N. A. H., Ariffin, N. M., \& Arshad, A. H. M. (2019). Impact of "Think-Pair-Share" and "Wait-Time" on Teaching and Learning Undergraduates: An Action Research. International Journal of Academic Research in Business and Social Sciences, 9(7), 843-861.

Copyright: (C) 2019 The Author(s)

Published by Human Resource Management Academic Research Society (www.hrmars.com)

This article is published under the Creative Commons Attribution (CC BY 4.0) license. Anyone may reproduce, distribute, translate and create derivative works of this article (for both commercial and non-commercial purposes), subject to full attribution to the original publication and authors. The full terms of this license may be seen

at: http://creativecommons.org/licences/by/4.0/legalcode

Vol. 9, No. 7, 2019, Pg. 843 - 861

Full Terms \& Conditions of access and use can be found at http://hrmars.com/index.php/pages/detail/publication-ethics 


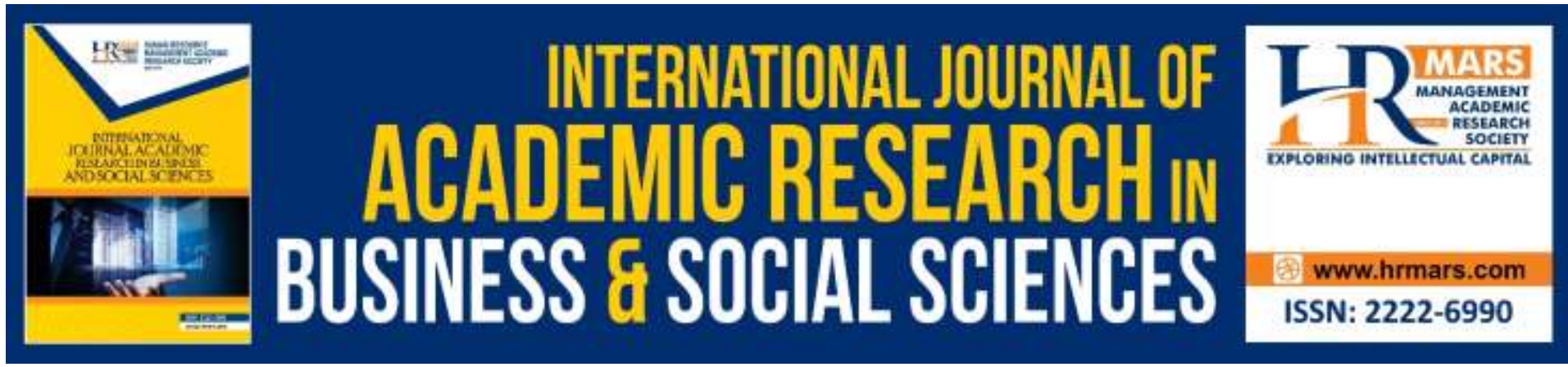

\title{
Impact of "Think-Pair-Share" and "Wait-Time" on Teaching and Learning Undergraduates: An Action Research
}

\author{
Ani Munirah Mohamad, Eshaby Mustafa, Nur Aili Hanim \\ Hanafiah, Nurhazlina Mohd Ariffin, Ain Husna Mohd Arshad \\ Email: Universiti Utara Malaysia, Malaysia
}

\begin{abstract}
The teaching and learning landscape in higher learning institutions are changing from teachercentered to student-centered learning. However, the students' lack of engagement in classrooms is found to become one of the drawbacks in the implementation of studentcentered learning. Aiming to address the problem of students' lack of engagement, this research is carried out to investigate the impact of two teaching strategies i.e. 'think-pairshare' and 'wait time' on the teaching and learning of undergraduates. The methodology employed in the study is qualitative, engaging in action research design and divided into three stages of study, (i) problem identification (ii) action implementation, and (iii) evaluation. Two cycles of investigation were carried out, involving the implementation of "think-pair-share" in the first cycle, and in the second cycle, "think-pair-share" and "wait-time". The data sources for the evaluation were three-folds, (i) lecturer's observation (ii) reflection by the students and lecturer, and (iii) activity sheets by the students. The data are loaded into the computerassisted qualitative data analysis software of ATLAS.ti version 8 for the purpose of analysis and generating the reports of the analysis. The study revealed that both teaching strategies of "think-pair-share" and "wait-time" have tremendously improved the student engagement in the classes. Additionally, the students' learning experience have enhanced with the implementation of these two teaching strategies. And finally, the lecturer's teaching ability also improved. Hopefully, the findings of the study would contribute to the literature on the subject of student engagement and teaching and learning strategies particularly, and other subjects of the higher education level generally.
\end{abstract}

Keywords: Think-Pair-Share, Wait-Time, Teaching and Learning, Higher Education, Student Engagement

\section{Introduction}

"Students must actively process information in order to learn" (Sampsel, 2013). Essentially, this means that active students process information better, for the purpose of learning the 
lessons taught to them. Lack of engagement in class may lead to low-level of critical thinking and lack of motivation. Active engagement in classroom is the result of commitment from both the teacher and the students. In this aspect, "think-pair-share" and "wait-time" are two teaching and learning techniques that may help increase student engagement and participation in classroom.

This action research was conducted to study the effects of implementation of these two learning strategies within the context of undergraduate students of the higher learning institution. The class that has been selected for this research is a law class, which is Jurisprudence. Five teachers have decided to participate in this research action project, one is them is teacher-researcher, and another four are teacher-participants. The research was conducted in two cycles to test the impact of "think-pair-share" alone and "think-pair-share" coupled with "wait-time".

\section{Problem Statement}

This action research was conducted based on the ground that the researchers have identified a serious issue in classroom, which is students' lack of engagement. This issue was identified through three instruments, i.e. teacher's observation, reflection and online survey. Observation is conducted by the teacher-researcher in a series of classes at the beginning of the semester. From her observation, the teacher noticed that there are few students who did not give proper attention, not responsive, lack of curiosity and interest into the subject matter and tend to become passive learners rather than active learners.

As a result of this observation, a reflection is written by the teacher-researcher to evaluate, analyse and suggest an action plan to overcome the situation. This is where "think-pair-share" and "wait-time" come into picture.

To strengthen the process of identification of problem, a set of online survey question was distributed to students. The objective of this survey is to understand students' preferences in learning and their expectations from the course. A total of 25 students had answered the survey questions. Based on the result, $52 \%$ of the students are kinesthetic, $32 \%$ visual, and only $16 \%$ audio. Despite majority of them are kinesthetic, only $28 \%$ of the students prefer to have class activities such as group discussion, games and role play. $12 \%$ prefer online learning, whereas the majority $60 \%$ prefer to have traditional lecture. When asked about their expectation from the lecturer, there are a few students who expect the lecturer to play active role, instead of the students themselves. One student specifically mentioned that he/she expects to have a lecture that focuses on teaching rather than unnecessary grouping, games or mind-mapping.

Based on the above discussion, it was decided that the issue relating to student engagement in class need to be properly addressed through certain action plan. Hence, this research was carried out to investigate the impacts of the learning strategies of think-pair-share and waittime on teaching and learning of undergraduates.

\section{Research Questions}

Three research questions are investigated in this study:

$1 \quad$ How does "think-pair-share" impact on student engagement in class? 
How does "think-pair-share" coupled with "wait-time" impact on student engagement in class?

\section{Conceptualising Strategies for Student Engagement}

A number of strategies have been identified as the key concepts of this action research, namely teaching and learning undergraduates, "think-pair-share" and "wait-time". Each of these strategies are elaborated in detail in this section.

\section{Teaching and Learning Undergraduates}

Undergraduates of higher learning institutions are learners who have successfully completed their secondary or high school, but yet to undergo postgraduate courses. Tackling the teaching and learning of undergraduates therefore require a proper planning and approach so that the inclinations of the students are appropriately addressed, and the teaching and learning strategies are suitable for the students' learning styles. Accordingly, one of the biggest issues in teaching and learning undergraduates is lack of engagement in classes. Student engagement in the classroom is very essential, as from the observation that far too many students are bored, unmotivated, and uninvolved, that is, disengaged from the academic and social aspects of academic life. Trowler (2010) defines student engagement as an interaction between the time, effort and other relevant resources spent by both students and their instructor or institutions. The ultimate outcome is in fact to increase the students' learning experiences and achieve the learning objectives intended by the course. Ultimately, this can be summarized as completing the course learning outcomes for the specific course. Engagement is differentiated by two components, social and academic. The social component of engagement refers to the behavioral aspect of the students towards the learning process, such as early attendance to classes, completion of the assignments on time, and the attitude towards the teacher and their classmates in the classes. The academic component of student engagement is the attitude of the students towards the lecturer and the lecture itself, such as active participation, increased interaction with the lecturer and the like. For this model, both types of engagement are vital for understanding the process that triggers school or class dropout (Archambault, Janosz, Fallu, \& Pagani, 2009). Similarly, Fredricks, Blumenfeld, \& Paris (2004) seemed to agree with these components, as they opined that student engagement is actually a magnitude of various determinants such as behavioral, affective and cognitive.

For that reason, the authors are interested in investigating student engagement in classroom activities as a mediator between teacher behavior and student achievement or participation. Thus, this study attempts to highlight an activity that can be carried out in the classroom to increase the participation of students in the classroom. Among the proposed activities are "think-pair-share" coupled with "wait-time".

\section{"Think-Pair-Share" for Enriching Learning Experience}

It is believed that discussion is an integral part of a successful teaching and learning session as it allows teachers to gain insights into the student's understanding. Discussion conducted in a small group especially, allows the student to practice expressing their understanding and constructing arguments based on the lesson content and instruction given in class. It is an 
important skill to possess throughout lifelong learning. Furthermore, this may help students build up their confidence in developing critical thinking and correct their own misconception. Confidence in learning is closely related to cooperative learning where several techniques such as think pair share can be applied by assisting students to conduct discussion after each of them were given time to individually think about the answers (Sampsel, 2013). Next, is to pair the student to another partner, share their findings and try to compare their answer and enrich the answers with that they learnt from each other. All of the findings will be discussed with the other class members. This session expedites students' participation and interaction in class and allows them to respect others' view on similar topics discussed.

The think-pair-share technique encourages positive interdependence by encouraging the student to learn and making sure that their friend learns as well (Johnson \& Johnson, 1999). Each of the student's success also rests on their friend's success. They will learn to recognize their significance in the learning process, and to value each other's resources and perspectives by engaging the ideas together (Johnson \& Johnson, 1999).

Reinhart (2000) conducted a study to improve his teaching by using think-pair-share to incorporate cooperative learning techniques. Among the benefits of think pair share suggested by Reinhart (2000) are:

1. helped to improve class discussions

2. allowed students time to think individually

3. increased individual accountability and personal responsibility for learning and participation in class

4. students were more willing to share ideas with the whole class

5. chance to develop deeper understanding of class material

6. the researcher was able to better see what students understood

\section{Role of "Wait-Time" in Improving Student Engagement}

The concept of "wait-time" as an instructional variable was invented by Mary Budd Rowe (1974). When human received information, our mind may need variable time to process everything as it depends on our previous knowledge about it. There is some consideration need to be made in deliberating how long teachers have to wait for the students' response because their ability to think about the answers varies. Therefore, when student engagement in class are required, the techniques applied must be coupled with wait time to increase participation. Allocation for wait time can be revised over time depending on the level of student engagement and understanding. This information may be gathered from the students' response and discussion session during the think pair share session.

On this note, Rowe (1986) stated that 'wait time' offers opportunity to build up upon students' ideas and prompting the students to continue developing those ideas. However, it is also important to identify the type of questions that require 'wait time', because as mentioned in Kirton et al. (2007), students reported to experience boredom when they are asked to wait even when they already knew the answer. Therefore, teachers need to carefully select the type of questions and plan out how long the 'wait time' should be. 


\section{Methodology}

The research was carried out covering two main important components, first is research approach which is qualitative methods and the second is research design, which is action research. There are many methods in conducting action research in example quantitative method and qualitative method. For our action research, we use qualitative method. The purpose of qualitative method is to gather detailed thoughts of human behavior. For this research, it is focused on the behavior of students and their engagement in classroom.

\section{Research Approach and Design}

The rationale for using qualitative method in this research is to primarily concern in gaining direct experience from students and lecturer that involved in class regarding teaching and learning. According to Yin (2011), qualitative approach is a helpful way of understanding physician-patient and teacher-students, which are peer-peer relationships in their real-world settings. Qualitative method was significant in this research to investigate the element of why students' lack of engagement in class. To investigate this problem, we use the method of observation, survey from the students by looking at their expectation and reflection by participants' observer and lecturer involves in the class.

Consequently, the research design that have been developed in this research was action research. Action research is a structured method in which teachers recognize, observe and improve aspects of their practice. According to Mills (2003), action research also called as teacher research and teacher-as-researcher is an approached design to develop and improve teaching and learning. Action research provides teachers the opportunity to work together on common issues or everyday concern in their classrooms. In this research, our concern is more to identify the problem why engagement of students still lacking in classroom, engagement of students here more to interaction of time, effort and other resources between students and teachers in process of teaching and learning in higher education. Our research also focusing on activities of think-pair-share and wait-time impacted on student engagement in class.

\section{Data Collection}

After the initial planning to carry out this action research, the next stage of the study is action in which the data collection process takes place. There are two main stages in collecting data. The first stage involves problem identification, while the second stage involves intervention. In the first stage of this action phase, the researcher first identified the problems using three methods of observation, reflection and survey. From the observation in the classroom, feedback or reflection conducted by fellow lecturers or students, and a survey at the beginning of the current course semester, we found that the main problem of the student was lack of engagement in the classroom.

Most of the students from the legal program are found to be less or harder to respond when questioned by the lecturers in the classroom, or show less interest in the behavior or expression while in the classroom. Besides, feedback from some critical friends and students also found a lack of student's engagement. Moreover, the lack of involvement in the classroom can be also demonstrated through a brief study conducted during the start of the course at the beginning of the semester. The findings show that the majority of students from 
legal programs prefer to traditional lectures as opposed to carrying out activities in the classroom. This situation may be due to the natural state of the law that focuses more on objective and factual elements than subjective elements.

After the problem statement was identified, two proposed activities were projected to be used in a legislative class to see its effectiveness in improving student's engagement. The activities are, at the first cycle, "think-pair-share" as a single strategy, and at the second cycle, "think-pair-share" coupled with "wait-time" as a combined strategy. In the first cycle, the researchers try to carry out "think-pair-share" activities only in the class where students are given a piece of paper that contains some questions related to the topics discussed in the classroom. The student then needs to think the appropriate answer before discussing with his next friend. After brainstorming their ideas and views, students need to write the most accurate answers in the answer space to be presented in the classroom.

In the second cycle, the researchers try to carry out "think-pair-share" activity coupled with "wait-time" in the next class where students are still given a piece of paper containing some questions. However, this time students are given more time and space to think and discuss with their partner in getting accurate answers. Surprisingly, when time was given, students are more confident and volunteer to engage in discussions with friends and in the classroom as maybe they have more space for brainstorming and sharing their ideas in pairs. The example activity sheet is produced in Figure 1 below.

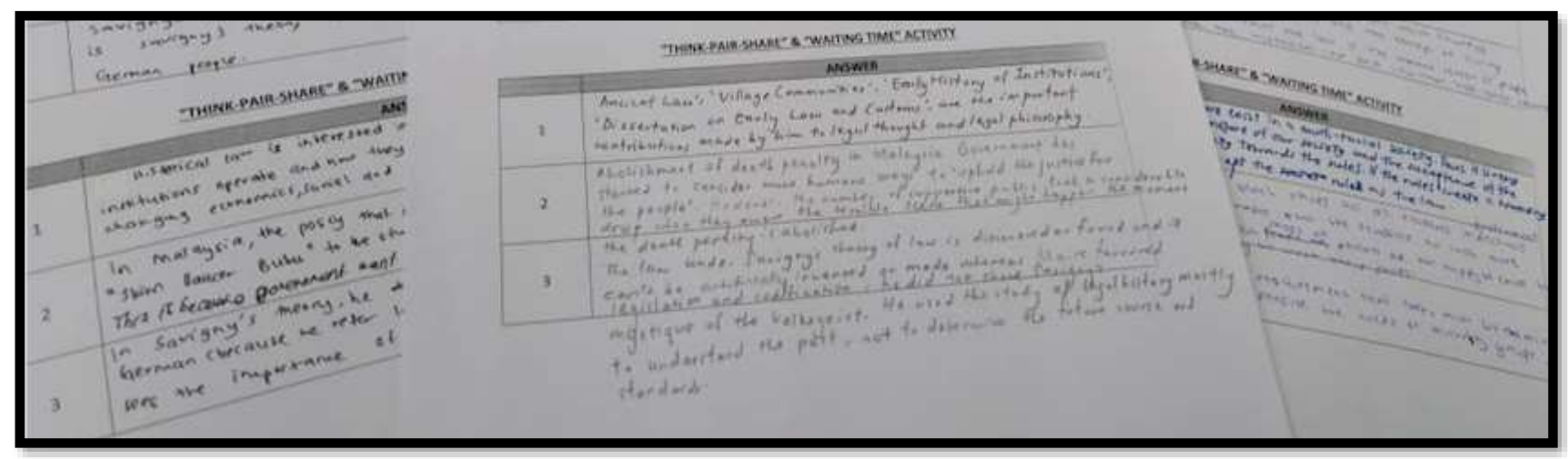

Figure 1. Example activity sheet for "Think-pair-share" coupled with "wait-time" activity conducted with the students

Three types of data were generated during each of the first and second cycles, hence collected for the purpose of analysis and generating the findings of the study are as follows:

1. Observation notes by the teacher,

2. Reflection notes by the students and teacher, and

3. Activity sheets which have been completed by the students.

Accordingly, the data sources for the study are as shown in Figure $\mathbf{2}$ below. 


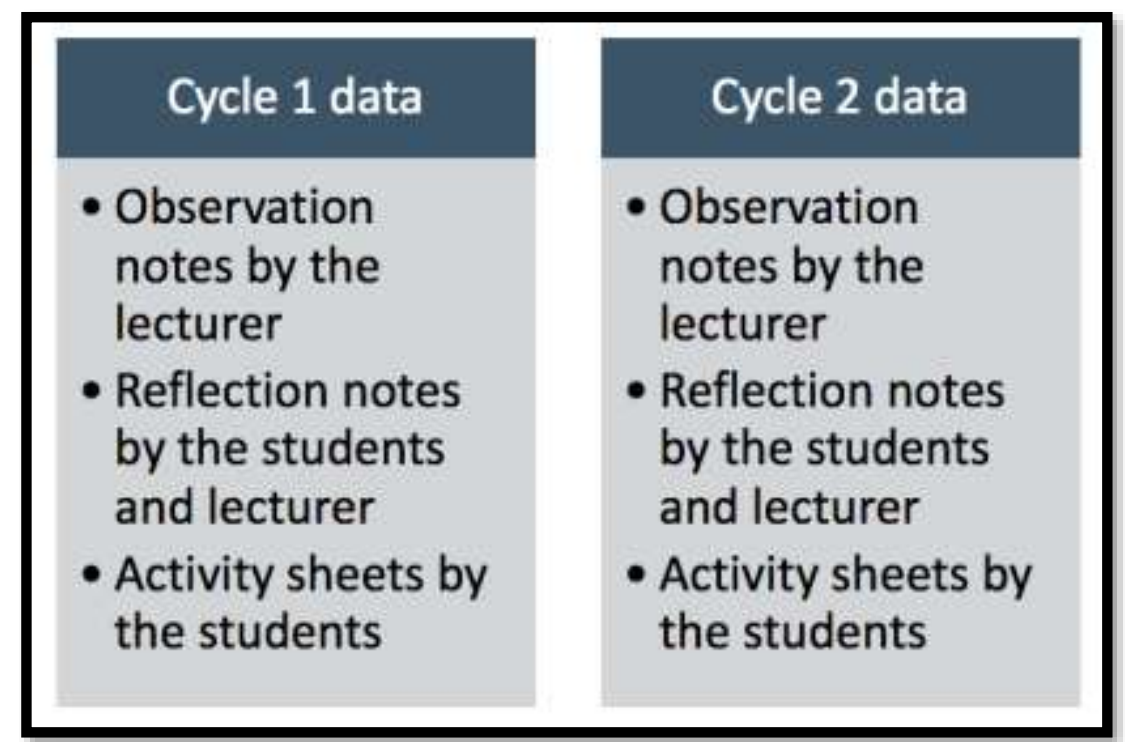

Figure 2. Data sources for the study

\section{Data Analysis}

The analysis process was carried out primarily to convert the raw data (observation notes, reflection notes and the activity sheets) into the format of interpretative texts (Miles, Huberman \& Saldana, 2014). This essentially means, although the researchers have the various data sources for the study in the form of observation notes, reflection notes and the activity sheets, their task at this point was to make sense of the raw data and interpret the data by employing the thematic analysis strategy (Boyatzis, 1998).

For the purpose of this study, the computer-aided qualitative data analysis software ATLAS.ti version 8 was engaged, particularly because it fits into the requirements of the data analysis for this qualitative research, being speedier than manual analysis (Duff \& Seror, 2005). First and foremost, the data were loaded into ATLAS.ti for the purpose of analysis and grouped according to the shared characteristics of Cycles 1 and 2, as well as being observation notes, reflection notes and activity sheets. The document groups are shown in Figure $\mathbf{3}$ below. 


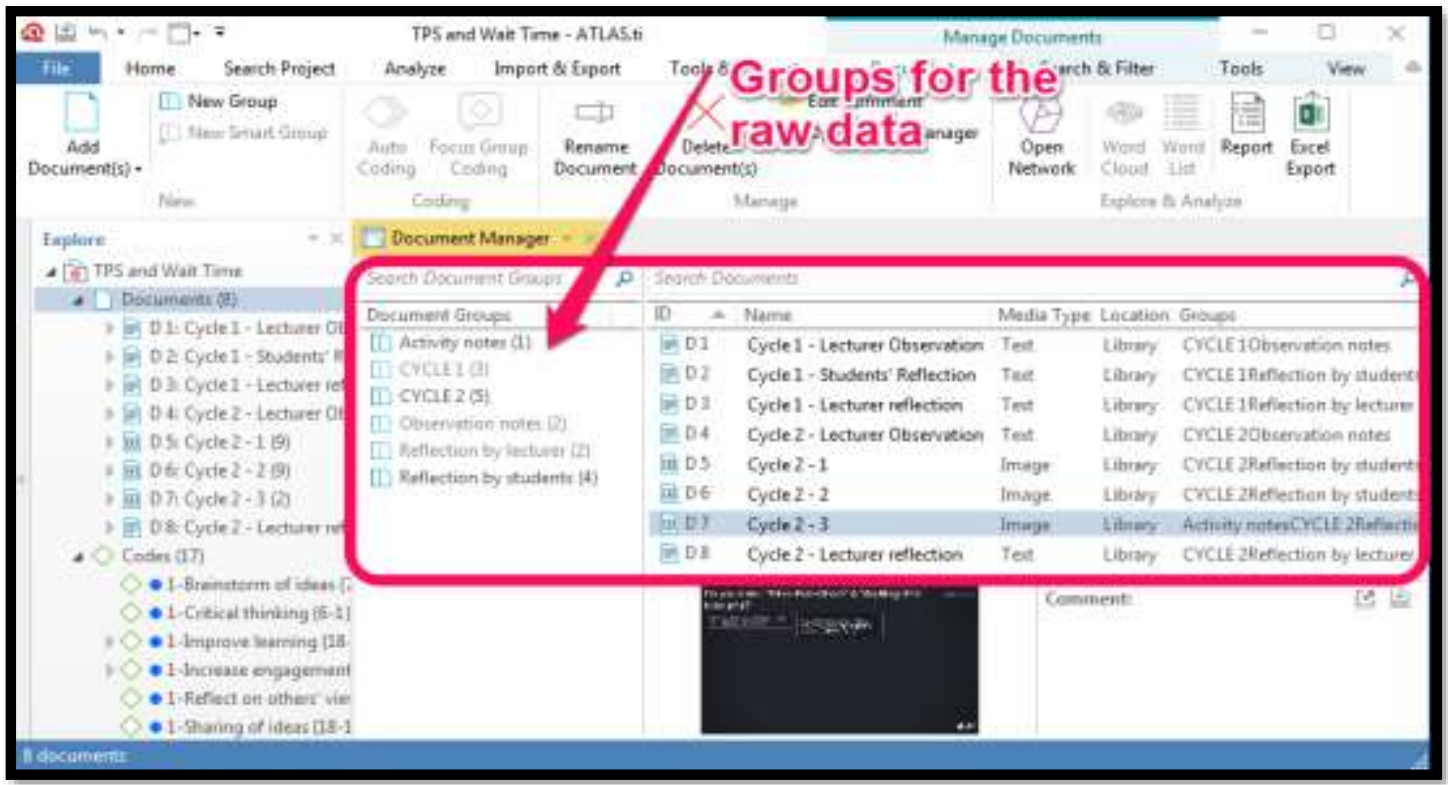

Figure 3. Document groups for the raw data in ATLAS.ti 8

Accordingly, each of the data was then coded by employing the thematic analysis strategy and guided upon the themes which have been generated in the study. In ATLAS.ti the coded data sections are linked to the themes and shown in-context. Example of the coded data sections are shown in Figures 4, 5 and 6 below.

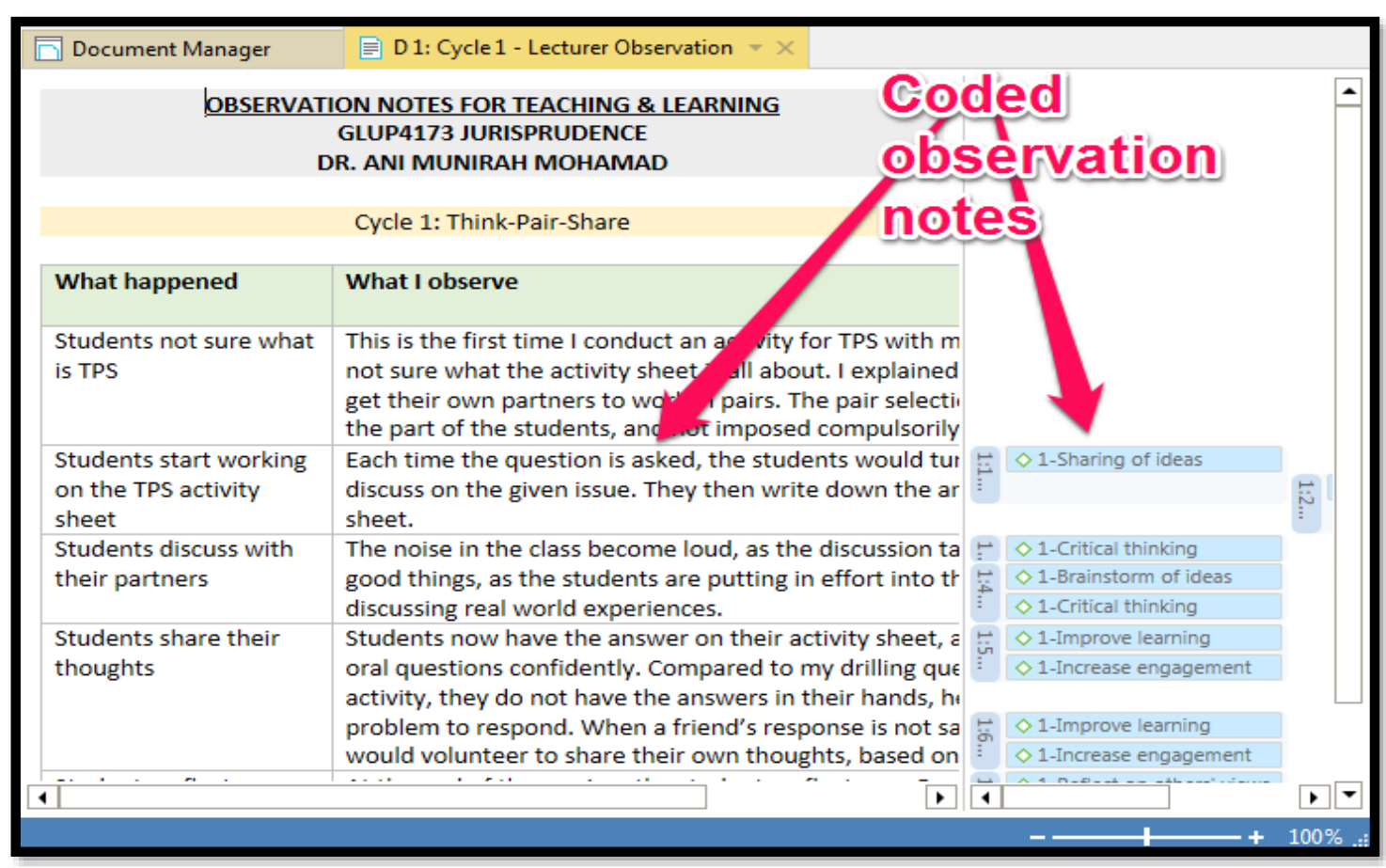

Figure 4. Example coded observation notes by the lecturer 


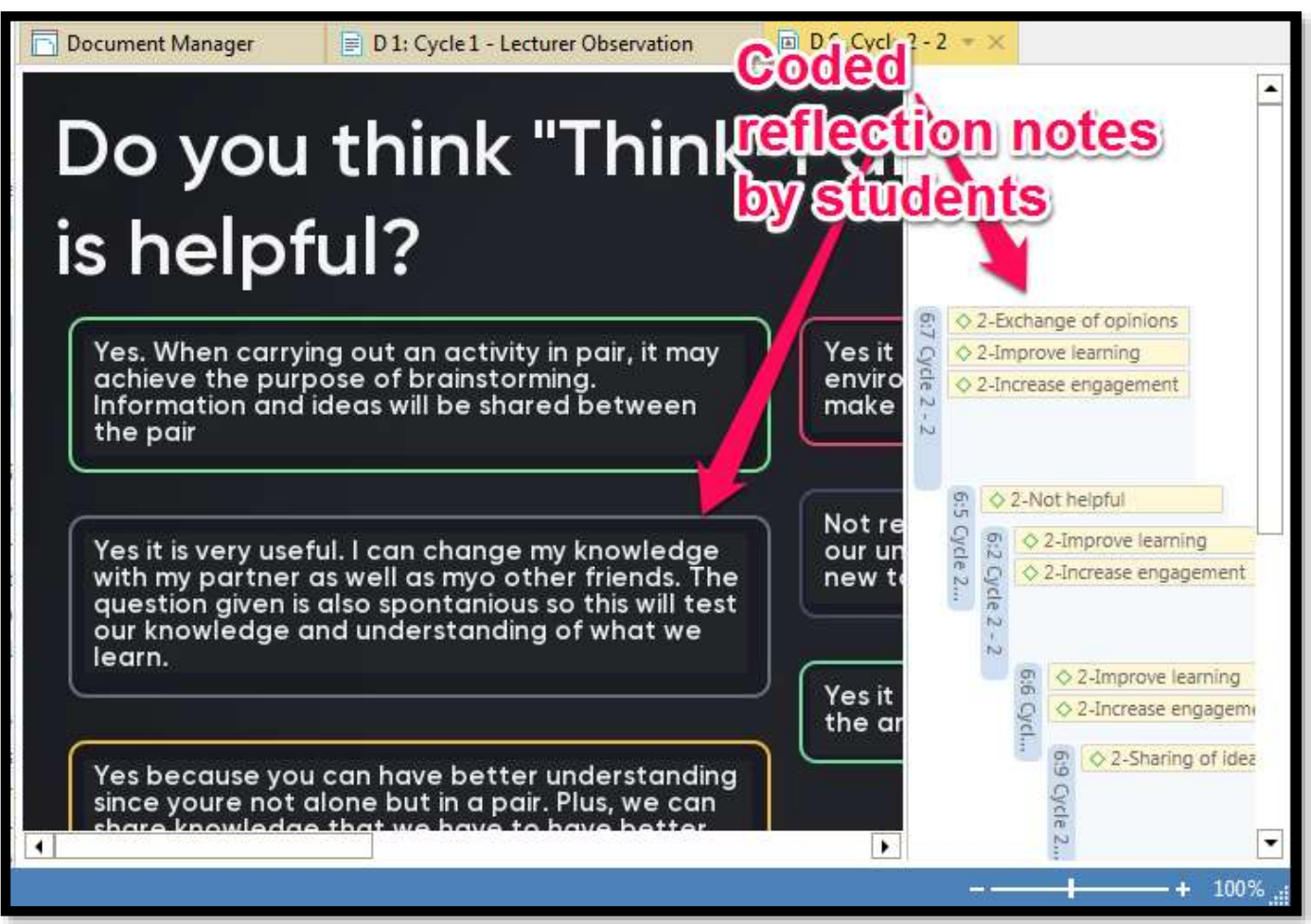

Figure 5. Example coded reflection notes by the students.

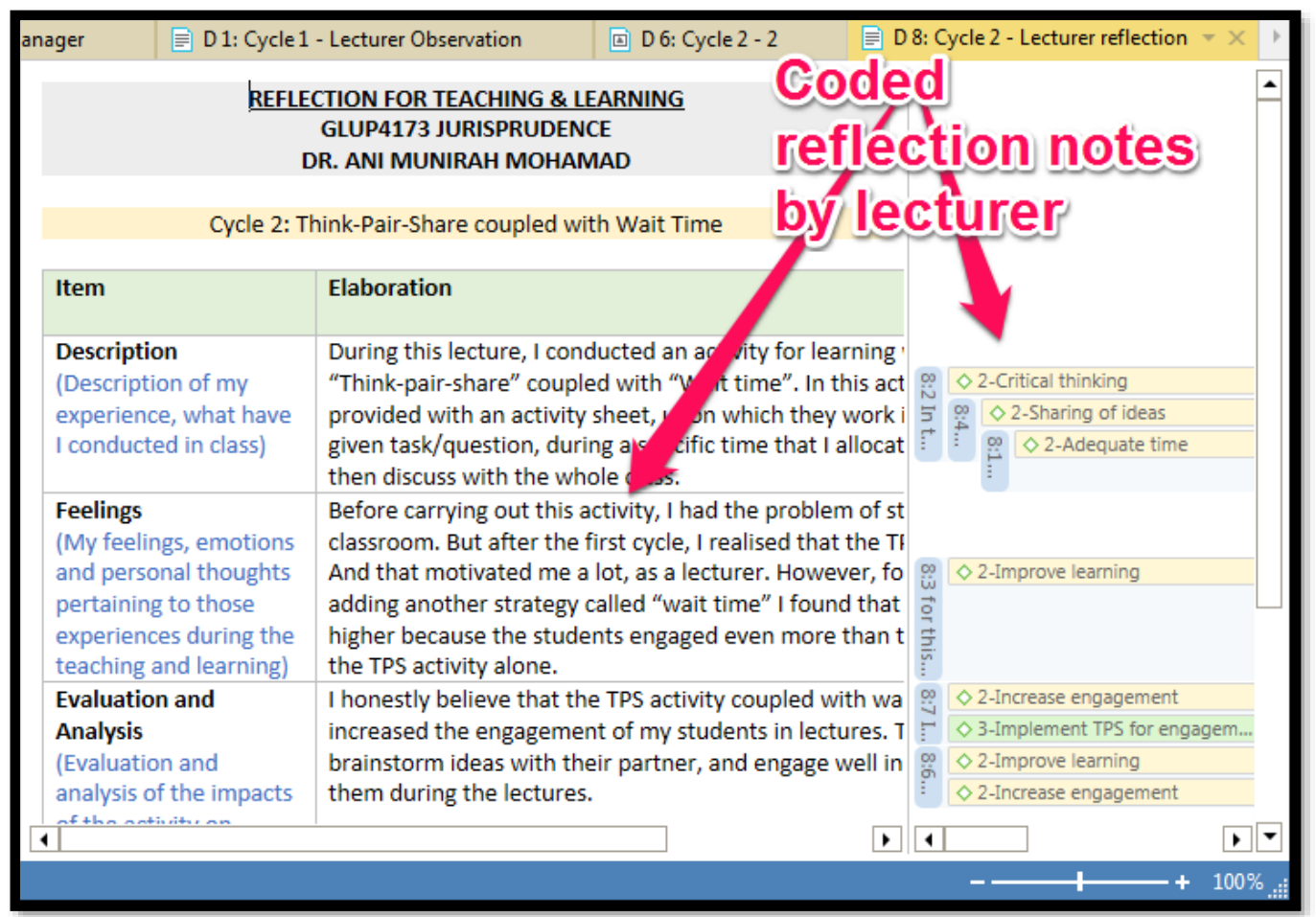

Figure 6. Example coded reflection notes by the lecturer

In this study, the themes comprised of the codes were build purely inductively by maintaining the specific words used by the participants in the data, and generalised to suit the main themes of the study. The researchers opted for the inductive reasoning of the data because this strategy would allow 
the researchers to maintain their objectivity of the analysis process by preserving the actual words used by the participants rather than the ones thought to be so by the researchers (Thomas, 2006). At the end of the analysis process, the themes were developed and produced by the output function in ATLAS.ti for the purpose of reporting. An example of the codes list and their respective themes are as shown in Figure 7 below.

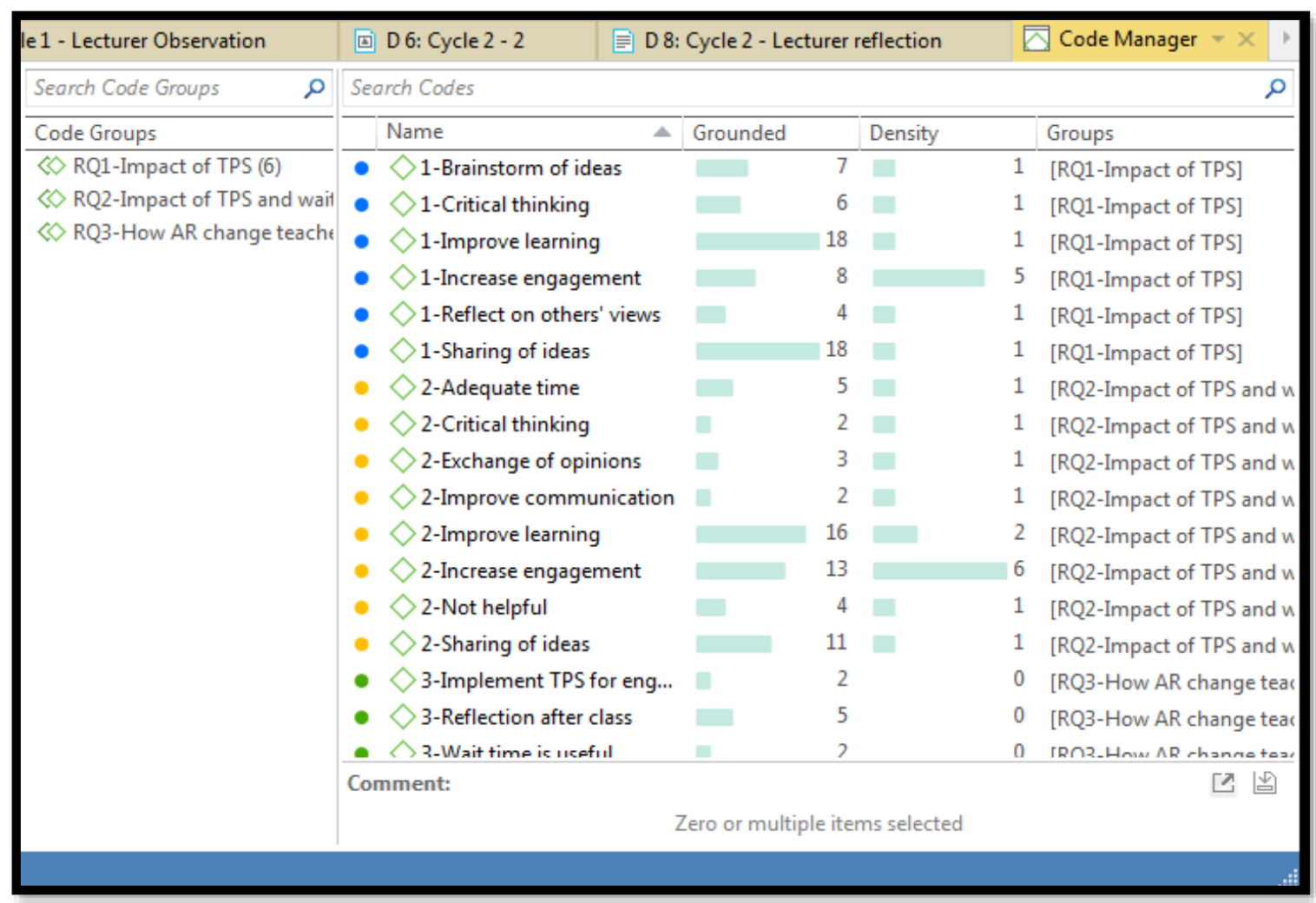

Figure 7. Codes list generated in the study

\section{Data Validity and Reliability}

For the purpose of determining the validity and reliability of the analysis and findings of the study, the researchers employed two main strategies in this study; (1) triangulation, and (ii) member checking. The first strategy is triangulation, it was employed in two different ways (1) the different data sources of reflection, observation and activity sheets, and (2) the different cycles of investigation i.e. Cycles 1 and 2 (Flick, 2004; Carter, et. al, 2014). What is pertinent to note in this strategy is that it came from the lenses of the researchers, hence often be clouded with objectivism. However, there was another validity strategy engaged in this study i.e member checking.

Member checking is the second validity strategy employed, particularly the raw data and the analysed data was then brought back to the participant for the purpose of endorsement and confirmation on what she meant the first time the data was generated and recorded (Birt, et. al, 2016). Upon confirmation by the lecturer involved that this finding be reported in this action research.

Accordingly, the combination of triangulation and member checking strategies employed in this study have indeed enhanced the validity and reliability of the data and findings of the study. Hence, the following findings are produced in the following part. 


\section{Findings and Discussion}

Upon completing the analysis process, three major findings have been generated from the data, coinciding with the three research questions of the study. This part elaborates the findings and discussion based on the three research questions identified earlier.

\section{Impact of "Think-pair-share" on Student Engagement in Class}

With regards to the first research question, on how does "Think-pair-share" impact on student engagement in class? The data revealed various keywords, which could be summarised into the following wordcloud in Figure $\mathbf{8}$ which was generated from the analysis of this particular research question in ATLAS.ti 8. As can be seen from the wordcloud, the keywords used by the participants include: "share", "discuss", "brainstorming" and "thoughts".

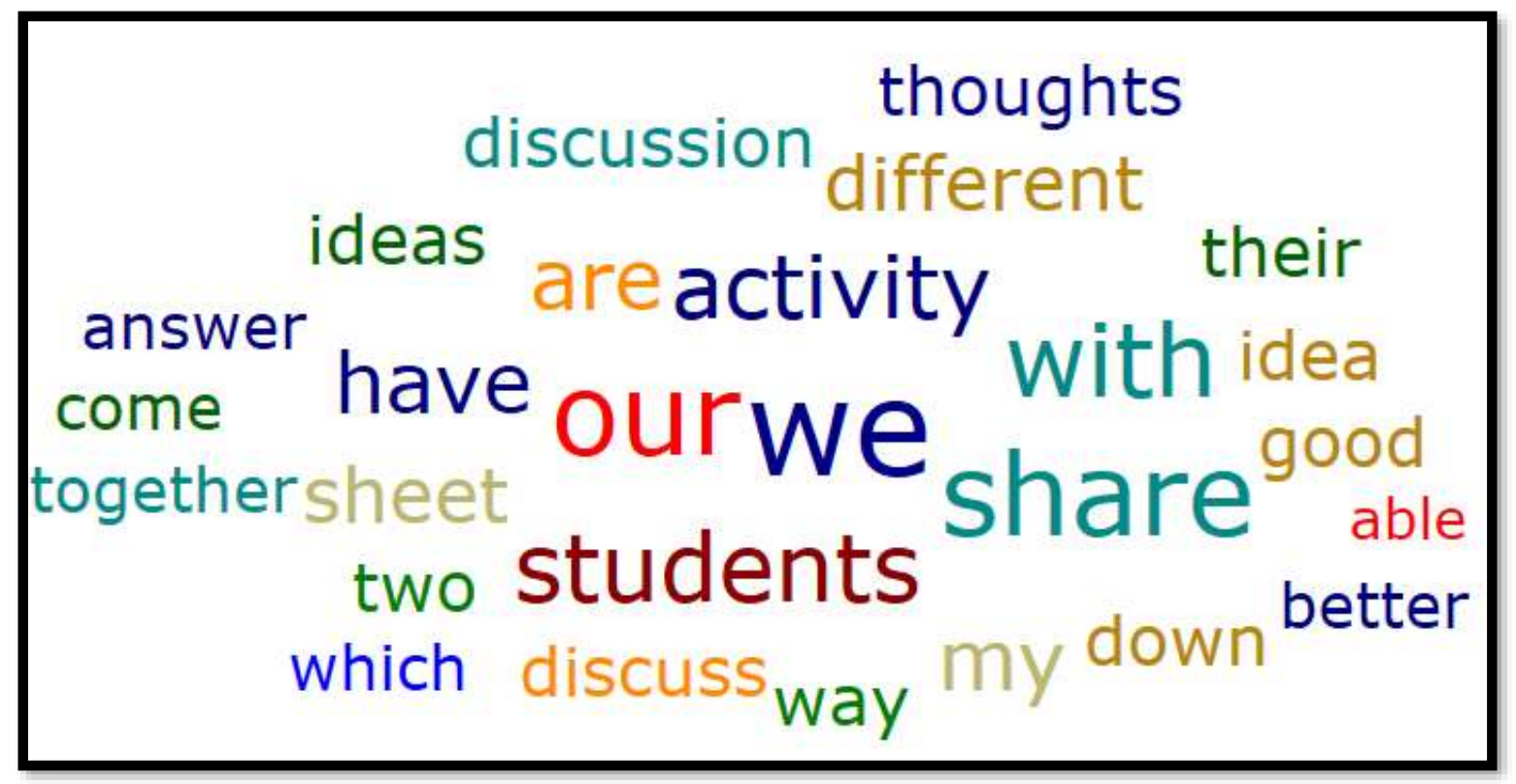

Figure 8. Word cloud on how does "Think-pair-share" impact on student engagement in class

Accordingly, the following findings in Figure 9 have been generated from the data sections with regards to the impacts of "think-pair-share" on student engagement in class. 


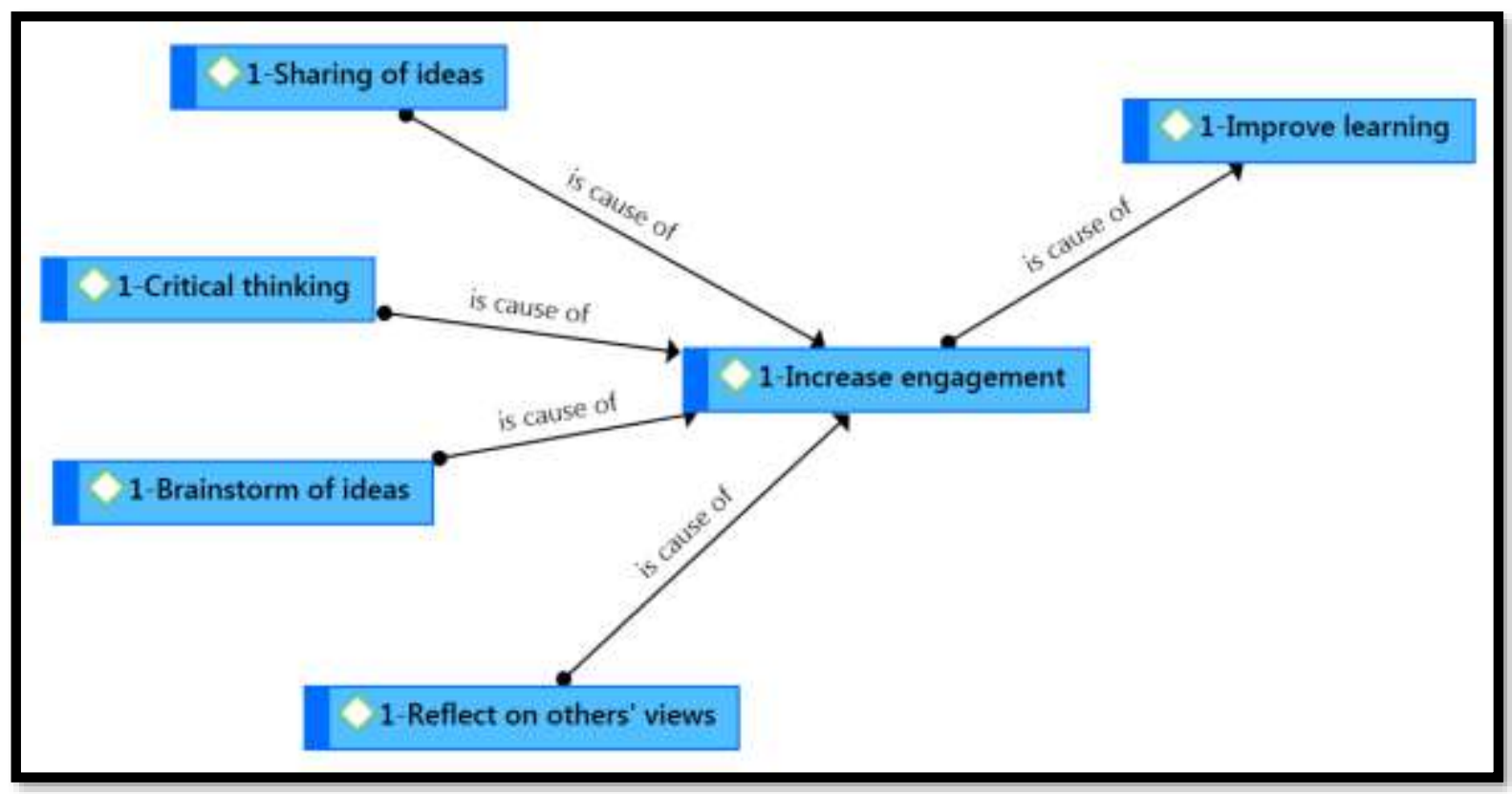

Figure 9. Findings on how does "Think-pair-share" impact on student engagement in class

The above diagram evidences that the "think-pair-share" activity indeed contributed towards the increased engagement by the students in class, by way of "sharing of ideas", "critical thinking", "brainstorming of ideas" and "reflect on others' views". Consequently, the increased engagement by the participants would lead to the improvement and enhancement of the learning experiences by the students. Few of the selected direct quotations from the participants are produced in Table $\mathbf{1}$ below.

Table 1. Quotations from participants on how does "Think-pair-share" impact on student engagement in class

\begin{tabular}{|l|l|}
\hline Theme & Selected direct quotations from the participants \\
\hline Sharing of ideas & $\begin{array}{l}\text { "Able to share our thoughts with partner" } \\
\text { "Each time the question is asked, the students would turn to their partners } \\
\text { and discuss on the given issue" }\end{array}$ \\
\hline Critical thinking & $\begin{array}{l}\text { "It is good for critical thinking" } \\
\text { "I feel motivated, seeing that my students become highly responsive to the } \\
\text { issues I post to them" }\end{array}$ \\
\hline $\begin{array}{l}\text { Brainstorming of } \\
\text { ideas }\end{array}$ & $\begin{array}{l}\text { "We can brainstorm ideas from different perspective" } \\
\text { "Could discuss and brainstorm idea with lecturer in other words have two- } \\
\text { way communication which is really enjoyful." }\end{array}$ \\
\hline Reflect on others & $\begin{array}{l}\text { "We can see the topic in other people perceptions." } \\
\text { "There may be } 2 \text { or more perspectives on a same issue. Thus, we are able to } \\
\text { view in different perspectives" }\end{array}$ \\
\hline
\end{tabular}

Impact of "Think-pair-share" coupled with "wait-time" on Student Engagement in Class

With regards to the second research question, on how does "think-pair-share" coupled with "waittime" impact on student engagement in class? The data revealed various keywords, which could be 
summarised into the following wordcloud in Figure $\mathbf{1 0}$ which was generated from the analysis of this particular research question in ATLAS.ti 8. As can be seen from the wordcloud, the keywords used by the participants include: "activity", "brainstorm", "opportunity" and "engaged".

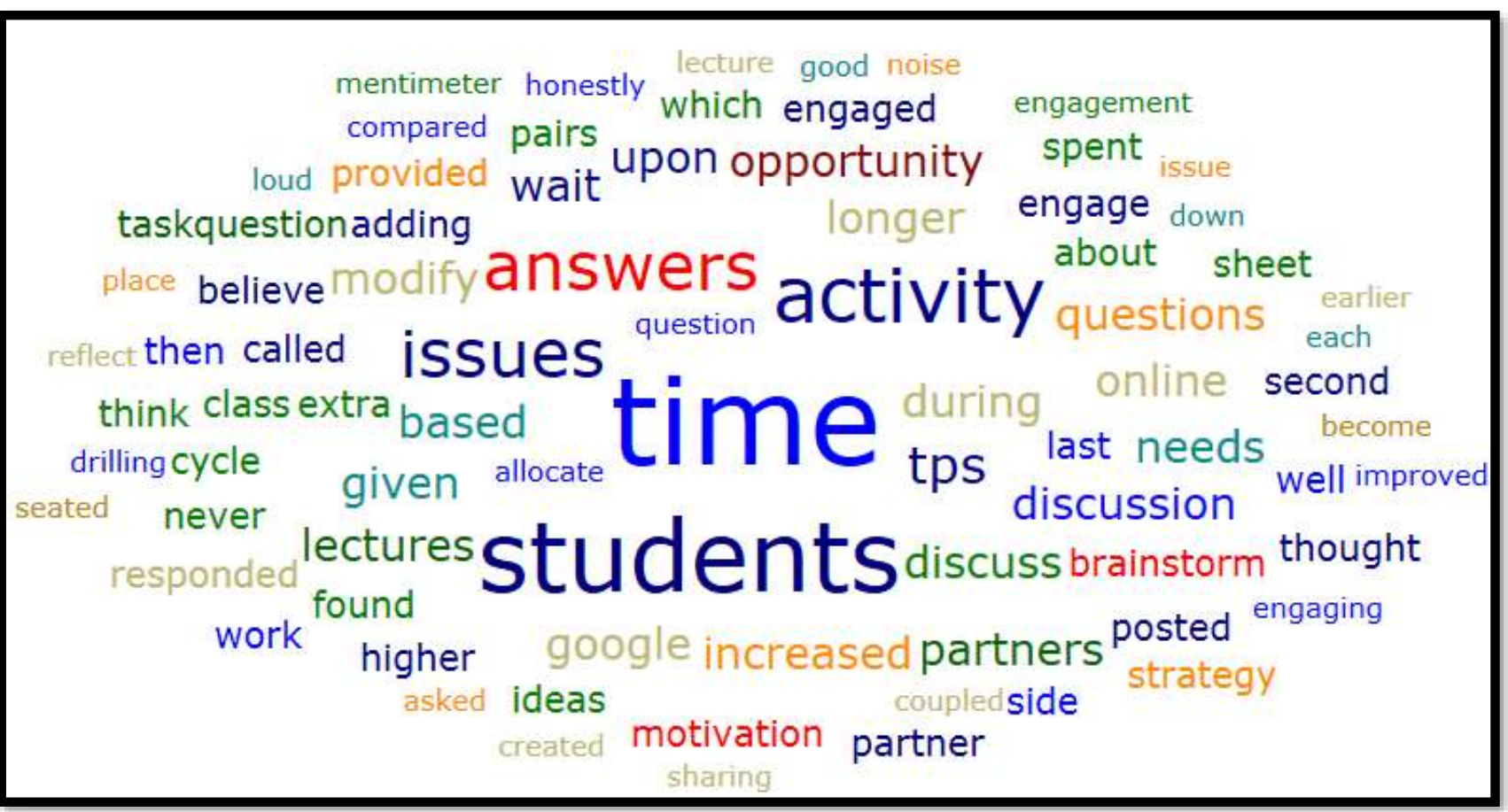

Figure 10. Word cloud on how does "Think-pair-share" impact on student engagement in class

Accordingly, the following findings in Figure $\mathbf{1 1}$ have been generated from the data sections with regards to the impacts of "think-pair-share" coupled with "wait-time" on student engagement in class.

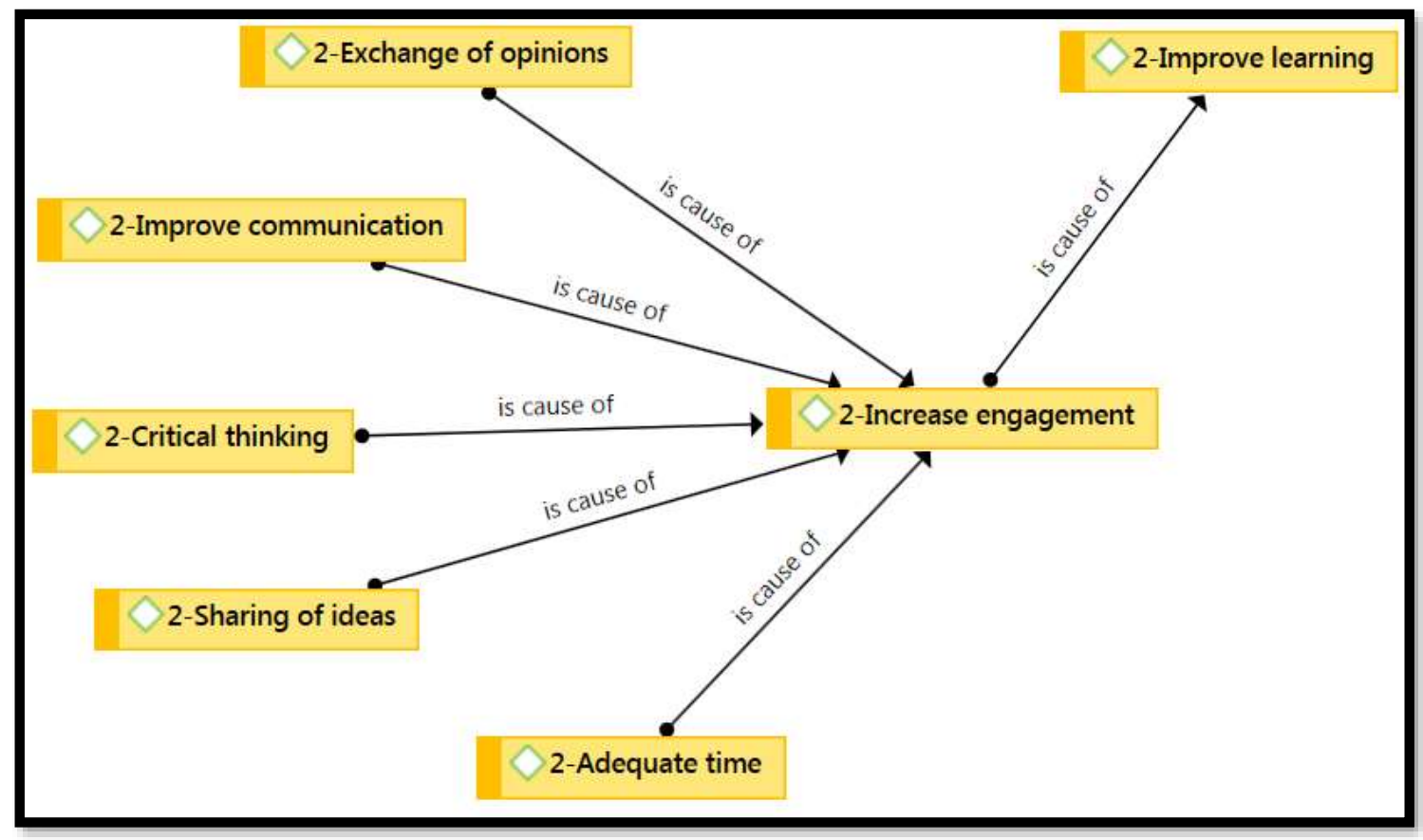

Figure 11. Findings on how does "think-pair-share" coupled with "wait-time" impact on student engagement in class 
The data from the second cycle had revealed that the "think-pair-share" activity coupled with "waittime" had indeed contributed towards the increased engagement by the students in class, by way of "exchange of opinions", "improved communication", "critical thinking", "sharing of ideas" and "adequate time". Consequently, the increased engagement by the participants would lead to the improvement and enhancement of the learning experiences by the students. Few of the selected direct quotations from the participants are produced in Table 2 below.

Table 2. Quotations from participants on how does "Think-pair-share" coupled with "wait-time" impact on student engagement in class

\begin{tabular}{|l|l|}
\hline Theme & Selected direct quotations from the participants \\
\hline Exchange of opinions & $\begin{array}{l}\text { "The noise in the class become loud, as the discussion takes place - which I } \\
\text { still believe is a good thing" } \\
\text { "Through this activity, we learn to exchange ideas without partner" }\end{array}$ \\
\hline $\begin{array}{l}\text { Improved } \\
\text { communication }\end{array}$ & $\begin{array}{l}\text { "We learn to communicate to come up with the answer" } \\
\text { "I learn to communicate better with my partner because we are helping }\end{array}$ \\
\hline Critical thinking & $\begin{array}{l}\text { "It helps us to learn in a critical environment" } \\
\text { "In this activity, the students are provided with an activity sheet, upon which } \\
\text { they work in pairs to think about the given task/question" }\end{array}$ \\
\hline Sharing of ideas & $\begin{array}{l}\text { "Yes, because we can share knowledge to gain better understanding" } \\
\text { "They are seated side by side with their partners, and waiting for the lecture } \\
\text { and the drilling questions by me" }\end{array}$ \\
\hline Adequate time & $\begin{array}{l}\text { "We got a certain time period to make a decision" } \\
\text { "This time, the students are provided with a longer time to discuss the } \\
\text { issue(s) with their partners" }\end{array}$ \\
\hline
\end{tabular}

\section{Impact of this Research in Improving Teacher-Researcher's Teaching Delivery}

With regards to the third research question, on how does this research improve teacher-researcher's teaching delivery? The data revealed various keywords, which could be summarised into the following wordcloud in Figure $\mathbf{1 2}$ which was generated from the analysis of this particular research question in ATLAS.ti 8. As can be seen from the wordcloud, the keywords used by the participants include: "improved", "engagement", "significant" and "understanding". 


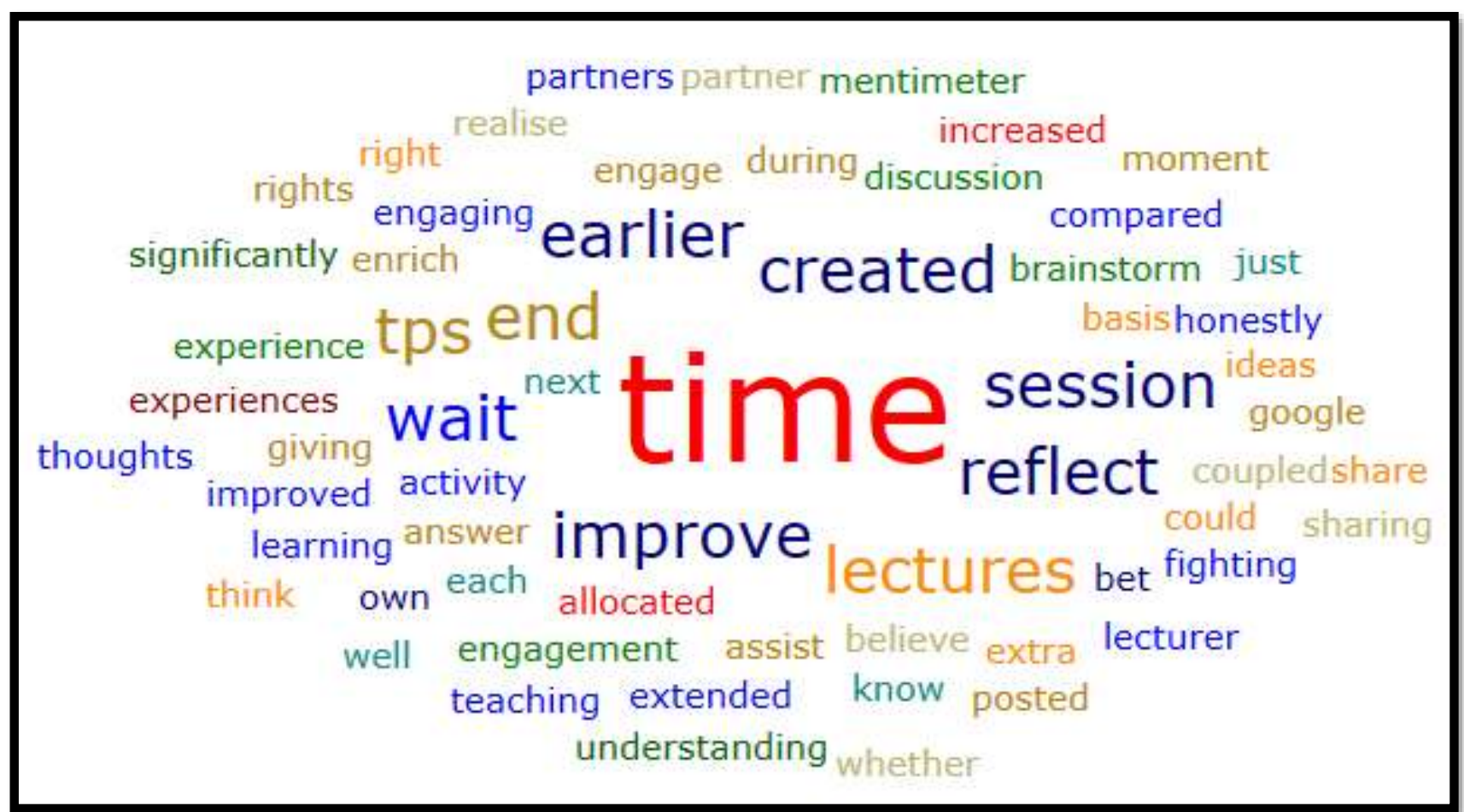

Figure 12. Word cloud on how this research improves teacher-researcher's teaching delivery

Accordingly, the following findings in Figure $\mathbf{1 3}$ have been generated from the data sections with regards to how does this research improve teacher-researcher's teaching delivery.

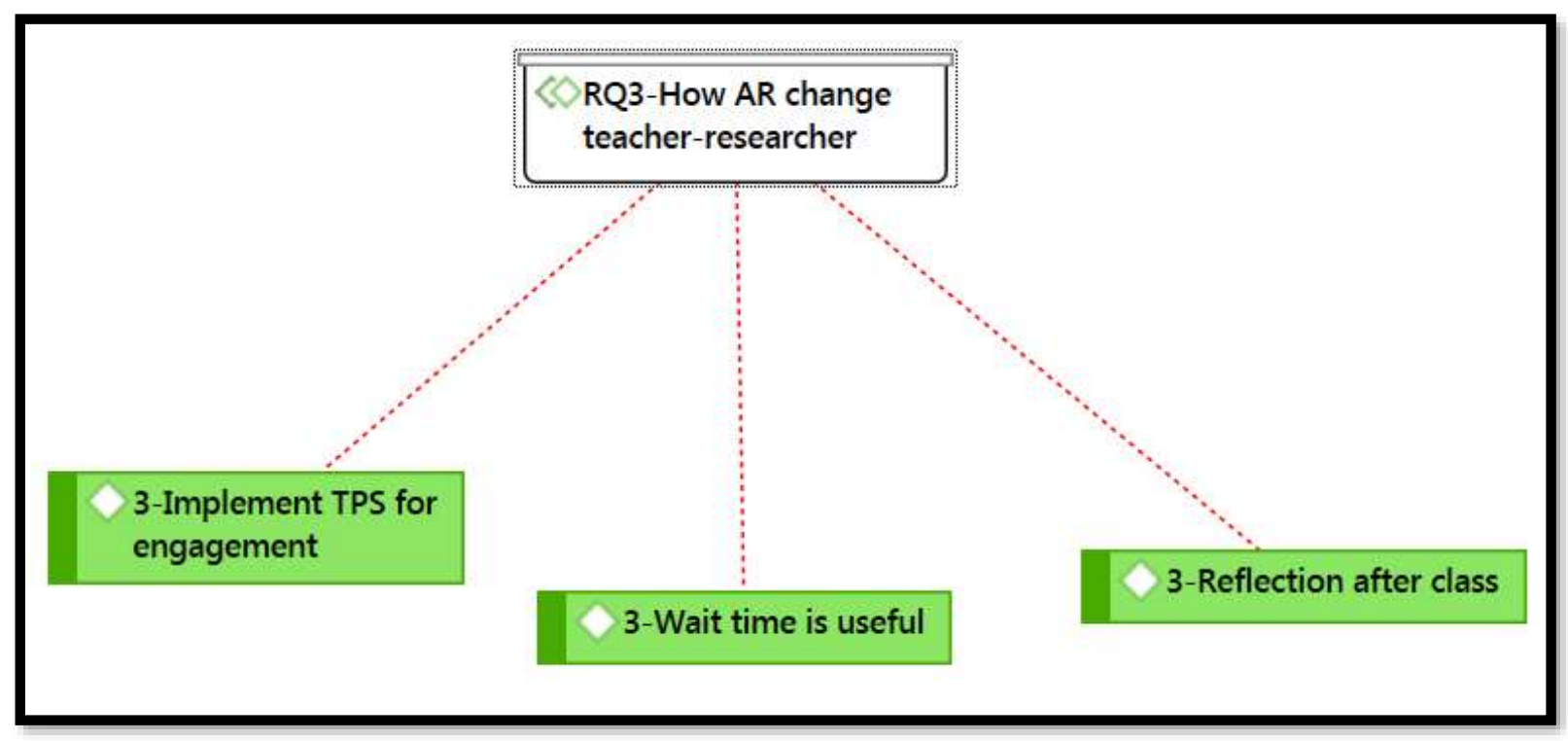

Figure 13. Findings on how this research improves

teacher-researcher's teaching delivery

In essence, this action research had changed the teacher-researcher in three main dimensions, the first one is that the implementation of "think-pair-share" would increase the engagement of the students in class. The second one is that the "wait-time" was proven to be useful in increasing the engagement of the students in class, and finally, the teacher-researcher learned that reflections 
should always be conducted by the end of each lesson with the students. Few of the selected direct quotations from the participants are produced in Table 3 below.

Table 3. Quotations from participants on how this research improves teacher-researcher's teaching delivery

\begin{tabular}{|l|l|}
\hline Theme & Selected direct quotations from the participants \\
\hline $\begin{array}{l}\text { "think-pair-share" } \\
\text { increases } \\
\text { engagement of the } \\
\text { students }\end{array}$ & $\begin{array}{l}\text { "I honestly believe that the TPS activity coupled with wait time have } \\
\text { significantly increased the engagement of my students in lectures" } \\
\text { "The sharing of thoughts by the students improved a lot, compared to } \\
\text { prior engaging in the TPS" }\end{array}$ \\
\hline $\begin{array}{l}\text { "wait-time" was useful to } \\
\text { increase engagement }\end{array}$ & $\begin{array}{l}\text { "They got the extra time to brainstorm ideas with their partner, and } \\
\text { engage well in the discussion I posted to them during the lectures." }\end{array}$ \\
\hline $\begin{array}{l}\text { Lessons learned by the } \\
\text { teacher-researcher from } \\
\text { the action research }\end{array}$ & $\begin{array}{l}\text { "I bet I could improve next time by giving the students more time to } \\
\text { think and share with their partners" } \\
\text { "At the end of the session, the students reflect on a Mentimeter form } \\
\text { created earlier by me." } \\
\text { "I realise that as a lecturer, I can improve in my teaching experience the } \\
\text { moment I assist my students to enrich their own learning experiences." }\end{array}$ \\
\hline
\end{tabular}

\section{Conclusion}

The researchers undertook this research in three major steps of action research, namely (1) problem identification, (2) implementation of intervention, and (3) evaluation. At the problem identification stage, the researchers concluded that the glaring problem in the teaching and learning of law undergraduates would be the lack of engagement in class. This was evident by way of the observation by the lecturer as well as the outcome of the survey administered on the students at the very beginning of the semester. The researchers then went on to identify two teaching instruments i.e. think-pair-share and wait-time.

The implementation of the intervention was carried out in two cycles, (1) first cycle - the implementation of think-pair-share as a single strategy, and (2) second cycle - the implementation of think-pair-share coupled with wait-time as a teaching strategy. During the intervention, three data sources were generated and collected for the purpose of analysis. Observation notes, reflection notes and activity sheets were triangulated and analysed primarily to address the three research questions of the study.

The study revealed three major findings: (1) the implementation of "think-pair-share" improved the student engagement in class, (2) the implementation of "think-pair-share" and "wait-time" improved the student engagement in class, and finally (3) the entire action research had improved the teaching ability of the teacher-researchers.

In conclusion, it is hereby emphasized that all three research questions have been addressed and answered correctly. Nonetheless, there are challenges facing the smooth implementation of the study, such as the diverse background and learning styles of the students, as well as the creative and innovative activities of the lecturer to be exercised by the students. However, greater challenges are facing the researchers in the coming years. When that time comes, the 
researchers would be strong in facing such challenges with another action research to be carried out.

\section{Acknowledgement}

The authors would like to extend their sincerest gratitude to Assoc. Prof. Dr. Aizan Yaacob from the UUM School of Education and Modern Languages for her teaching, advice and sharing of her meaningful experience with the authors.

\section{Corresponding Author}

Ani Munirah Mohamad

School of Law

College of Law, Government and International Studies

Universiti Utara Malaysia

animunirah@uum.edu.my

\section{References}

Archambault, I., Janosz, M., Fallu, J. \& Pagani, L. S. (2009). Student engagement and its relationship with early high school dropout. Journal of Adolescence, 32, 651-670.

Birt, L., Scott, S., Cavers, D., Campbell, C., \& Walter, F. (2016). Member checking: a tool to enhance trustworthiness or merely a nod to validation? Qualitative Health Research, 26(13), 1802-1811.

Boyatzis, R. E. (1998). Transforming qualitative information: Thematic analysis and code development. sage.

Carter, N., Bryant-Lukosius, D., DiCenso, A., Blythe, J., \& Neville, A. J. (2014, September). The use of triangulation in qualitative research. In Oncology nursing forum (Vol. 41, No. 5).

Duff, P. A., \& Seror, J. (2005). Computers and qualitative data analysis: Paper, pens, and highlighters vs. screen, mouse, and keyboard. Tesol Quarterly, 39(2), 321-328.

Flick, U. (2004). Triangulation in qualitative research. A companion to qualitative research, 3, 178-183.

Fredricks, J. A., Blumenfeld, P. C., \& Paris, A. (2004). School engagement: Potential of the concept: State of the evidence. Review of Educational Research, 74, 59-119.

Johnson, D. W., \& Johnson, R. T. (1999). Making cooperative learning work. Theory into Practice, 38(2), 67-73.

Kirton, A., Hallam, S., Peffers, J., Robertson, P., \& Stobart, G. (2007). Revolution, evolution or a Trojan horse? Piloting assessment for learning in some Scottish primary schools. British Educational Research Journal, 33, 605-627

Mills, G. (2003). Action Research: A guide for the teacher researcher. $2^{\text {nd }}$ ed. Upper Saddle River.

Miles, M. B., Huberman, A. M., \& Saldana, J. (2014). Qualitative data analysis. Sage.

Reinhart, S. C. (2000). Never say anything a kid can say! Mathematics Teaching in the Middle School, 5, 478-483. 
Rowe, M. B. (1974). Wait-time and rewards as instructional variables, their influence on language, logic, and fate control: Part one-wait-time. Journal of Research in Science Teaching, 11(2), 81-94.

Rowe, M. B. (1986). Wait time: slowing down may be a way of speeding up! Journal of Teacher Education, 37 (1), 43-50.

Sampsel, A. (2013). Finding the Effects of Think-Pair-Share on Student Confidence and Participation. Honors Projects Paper 28.

Thomas, D. R. (2006). A general inductive approach for analyzing qualitative evaluation data. American Journal of Evaluation, 27(2), 237-246.

Trowler, V. (2010). Student engagement literature review. Lancaster: Department of Educational Research Lancaster University.

Yin, R. K. (2011). Qualitative Research from Start to Finish. The Guilford Press. New York, London. 